\title{
Konflik dan resolusi konflik: Pendekatan analytical hierarchy process dalam konflik pertanahan di Urutsewu, Kebumen
}

\section{Susanto}

Peneliti Independen, Semarang

\section{INTISARI}

Artikel ini bertujuan untuk mencari alternatif dan model penyelesaian konflik pertanahan di Urutsewu Kebumen dengan menggunakan pendekatan Analytical Hierarchy Process (AHP). Konflik ini merupakan manifestasi dari persepsi dan preferensi yang berbeda yang terjadi pada pihak-pihak yang berkonflik. Hak dan kepemilikan tanah adalah penyebab utama konflik antara masyarakat Urutsewu dan TNI Angkatan Darat. Resolusi konflik alternatif diperlukan oleh orang-orang yang terlibat dalam konflik Urutsewu. Dalam menguraikan data, tulisan ini menggunakan pendekatan campuran sekuensial yang menekankan pada pendekatan kuantitatif dan kualitatif. Hasilnya menemukan bahwa alternatif resolusi berupa negosiasi dengan masing-masing pihak berhasil mencegah konflik semakin terbuka. Selain itu, persepsi masyarakat mengatakan bahwa mediasi adalah strategi yang baik untuk meredakan konflik juga mencari solusi atas persoalan yang terjadi di Urutsewu. Tidak itu saja, resolusi konflik juga harus menggunakan pendekatan yang demokratis, salah satunya dengan mengubah status tanah yang menjadi akar konflik dari state property menjadi common property.

\section{KATA KUNCI}

Konflik; Resolusi Konflik; Analytical Hierarchy Process

\section{Pendahuluan}

anah dan pola pemilikannya bagi masyarakat pedesaan khususnya masyarakat merupakan faktor penting bagi perkembangan kehidupan sosial, ekonomi dan politik masyarakat pedesaan di samping kehidupan sosial, ekonomi, dan politik masing-masing warga desa itu sendiri. Hal ini sesuai dengan pendapat Harsono (2005: 35) bahwa fungsi sosial tanah berarti hak atas tanah apa pun yang ada pada seseorang, tidak dapat dibenarkan tanahnya itu akan dipergunakan (atau tidak dipergunakan) semata-mata untuk kepentingan pribadinya, apalagi kalau hal itu merugikan masyarakat. Tanah merupakan komoditas yang sangat penting bagi manusia, adanya komoditas tersebut menjadikan tanah yang ada di Indonesia sangat rentan terhadap

Korespodensi:

Email: santozaq@gmail.com 
munculnya konflik. Berdasarkan amanat Pasal 33 Ayat (3) Undang-Undang Dasar Negara Kesatuan Republik Indonesia 1945 dan Pasal 1 Ayat (2) Undang-Undang Nomor 5 Tahun 1960 tentang Peraturan Dasar Pokok-Pokok Agraria (UUPA), salah satunya menegaskan bahwa bumi dalam hal ini berwujud tanah digunakan sebesar-besarnya untuk kemakmuran rakyat.

Konflik yang terjadi di daerah Urutsewu adalah konflik sosial yang merupakan konflik vertikal yaitu terjadi antara masyarakat dengan Tentara Nasional Indonesia Angkatan Darat (TNI AD) dalam hal memperebutkan lahan. Selain konflik dengan TNI AD terjadi pula konflik yang dipicu oleh adanya penambangan pasir besi di daerah Kecamatan Mirit dengan adanya perusahaan yang diberikan izin penambangan oleh pemerintah. Disebut sebagai daerah Urutsewu karena tanah yang menjadi konflik di daerah Urutsewu terletak di antara muara Kali Lukulo Desa Ayamputih di sebelah barat sampai dengan muara Sungai Wawar Desa Wiromartan. Luas total, daerah yang berkonflik ini memiliki panjang kurang lebih 22,5 km dan lebar 500 meter dari bibir pantai.

Konflik di Wilayah Urutsewu merupakan manifestasi perbedaan persepsi dan preferensi yang terjadi pada pihak yang berkonflik. Adanya hak kepunyaan terhadap tanah yang menjadi tombak terjadinya konflik dengan persepsi masing-masing pihak yaitu masyarakat dan TNI AD. Alternatif resolusi konflik diperlukan untuk mencegah konflik tersebut semakin, tentunya harus melibatkan pihak-pihak yang terlibat dalam konflik Urutsewu tersebut. Hal itulah yang menjadi dasar pentingnya alternatif resolusi konflik pada Konflik Urutsewu Kebumen melalui pendekatan Analytical Hierarchy Process (AHP).

AHP merupakan suatu model pendekatan yang memberikan kesempatan bagi para stakeholders yang terlibat secara langsung maupun pihak yang memiliki kepentingan dalam suatu permasalahan untuk dapat membangun gagasan-gagasan atau ide-ide dan mendefinisikan persoalan-persoalan yang ada dengan cara membuat asumsi-asumsi dan selanjutnya mendapatkan pemecahan yang diinginkannya. Penggunaan metode AHP menerapkan dengan cerdas pendekatan matematis yang komplekas namun berdasarkan pendekatan kualitatif yang dapat diterima oleh semua stakeholders. Untuk memperoleh hasil yang maksimal dari suatu permasalahan, langkah awal adalah memilih dan menentukan prioritas yang tepat dan selanjutnya melaksanakannya dengan benar. Upaya resolusi konflik pertanahan di wilayah Urutsewu harus segera dirumuskan dan dipecahkan, dengan menentukan prioritas model resolusi bukan dengan pemikiran "apa yang akan saya dapat dari upaya resolusi tersebut" tetapi melakukannya dengan pertimbangan ilmiah menggunakan metode AHP dan pertimbangan moral "model resolusi yang tercipta harus berdampak pada kepentingan bersama, bukan pada kepentingan salah satu pihak saja".

Bahwasanya persoalan pertanahan dan persengketaan tanah secara masal dapat mempengaruhi upaya membangun dan menguatkan Negara Republik Indonesia dan dapat merenggangkan kohesi nasional dalam wadah negara yang Bhineka Tunggal lka (Limbong, 2012: 86). Menurut Sumardjono (1982: 82) secara garis besar peta permasalahan tanah dapat dikelompokkan menjadi 5 yaitu; masalah penggarapan rakyat atas tanah areal perkebunan, kehutanan, proyek perumahan yang diterlantarkan dan lain-lain; masalah yang berkenaan dengan pelanggaran ketentuan landreform; ekses-ekses dalam penyediaan tanah untuk keperluan pembangunan; sengketa perdata berkenaan dengan masalah tanah; dan masalah yang berkenaan dengan Hak Ulayat masyarakat hukum adat. 
Menurut Nader \& Todd (ed.) (1978: 186-188) para pihak dapat mengembangkan beberapa strategi atau alternatif dalam menyelesaikan sengketa seperti: lumping it atau membiarkan saja kasus itu berlalu dan mengangap tidak perlu diperpanjang; avoidance atau mengelak yaitu adalah cara penyelesaian di mana pihak yang merasa dirugikan memilih untuk mengurangi hubunganhubungan dengan pihak yang merugikan atau memilih untuk menghentikan hubungan; coercion (paksaan) adalah cara penyelesaian di mana satu pihak memberi paksaan terhadap pihak lain; negotiation (perundingan) adalah cara penyelesaian di mana kedua belah pihak telah menyepakati pengambilan keputusan tanpa adanya pihak ketiga; mediation adalah cara penyelesaian dengan melibatkan pihak ketiga sebagai perantara untuk membantu kedua belah pihak yang berselisih pendapat guna menemukan kesepakatan; arbitration (arbitrasi) adalah cara penyelesaian di mana kedua belah pihak sepakat untuk meminta perantara pihak ketiga yaitu arbitrator; adjudication (peradilan) adalah cara penyelesaian di mana pihak ketiga mempunyai wewenang untuk mencampuri pemecahan masalah yang terlepas dari keinginan para pihak yang bersengketa. Fisher dkk., (2001: 22-25) juga menyatakan di dalam tujuan penyelesaian konflik diantaranya; mencegah timbulnya kekerasan dalam konflik; negosiasi; mediasi; dan abritasi.

Metode Analytical Hierarchy Process (AHP) dikembangkan oleh Thomas L. Saaty, seorang ahli matematika pada tahun 1980. Menurut Saaty (2008: 84) AHP diartikan sebagai "is an effective tool for dealing with complex decision making, and may aid the decision maker to set priorities and make the best decision". Secara umum metode ini adalah sebuah kerangka untuk mengambil keputusan dengan efektif atas persoalan yang kompleks dengan menyederhanakan dan mempercepat proses pengambilan keputusan dengan memecahkan persoalan tersebut ke dalam bagian-bagiannya, menata bagian atau variabel dalam suatu susunan hierarki, memberi nilai numerik pada pertimbangan subjektif tentang pentingnya tiap variabel dan mensintesis berbagai pertimbangan ini untuk menetapkan variabel yang memiliki prioritas paling tinggi dan bertindak untuk mempengaruhi hasil pada situasi tersebut.

Metode yang digunakan dalam penelitian ini adalah metode metode campuran sekuensial (sequential mixed methods) terutama strategi eksplanasi sekuensial, yaitu mengumpulkan dan menganalisis data kuantitatif kemudian mengumpulkan dan menganalisis data kualitatif. Dalam penelitian ini lebih menekankan pada metode kuantitatif. Fokus penelitian ini adalah pada alternatif resolusi konflik yang paling tepat terhadap konflik pertanahan di Urutsewu Kebumen yang berlangsung selama ini dan penelitian ini dilakukan pada tahun 2017. Dalam penentuan sampel perlu diperhatikan jumlah populasi yang ada. Sampel dalam penelitian ini terdiri terdiri dari 2 jenis sampel yang nantinya akan digunakan pada 2 jenis instrumen kuesioner yaitu kuesioner responden masyarakat dan kuesioner AHP. Sumber data dalam penelitian ini menggunakan sumber data primer dan sekunder. Data primer di dapat melalui penelitian langsung melalui kuesioner kepada masyarakat dan stakeholders terkait lainnya. Data sekunder merupakan sejumlah keterangan atau fakta yang diperoleh secara tidak langsung, tetapi melalui penelitian kepustakaan. Teknik pengumpulan data kuantitatif dilakukan dengan cara studi lapangan atau langsung pada saat kegiatan penelitian kepada masyarakat dengan analisis SPSS dan stakeholders dengan analisis Expert Choice. 


\section{Sekilas Konflik Pertanahan Urutsewu}

Urutsewu merupakan sebutan kawasan di Kabupaten Kebumen yang terletak di wilayah pesisir selatan. Wilayah Urutsewu terdiri dari 3 kecamatan di Kabupaten Kebumen yaitu Kecamatan Buluspesantren, Kecamatan Ambal dan Kecamatan Mirit. Urutsewu terdiri dari 21 desa di Kecamatan Buluspesantren, 32 desa di Kecamatan Ambal serta 22 desa di Kecamatan Mirit. Wilayah Urutsewu berbatasan langsung dengan Samudera Hindia, artinya terdapat 15 Desa di 3 Kecamatan yang berbatasan langsung dengan Samudera Hindia. Kecamatan Buluspesantren terdiri dari Desa Ayamputih, Setrojenar dan Brecong, sedangkan Kecamatan Ambal terdiri dari Desa Entak, Kenoyojayan, Ambal Resmi, Kaibon Petangkuran, Kaibon dan Sumberjati. Sedangkan Kecamatan Mirit terdiri dari Desa Mirit Petikusan, Tlogodepok, Mirit, Tlogo Pragoto, Lembupurwo dan Wiromartan.

Selain itu wilayah Urutsewu melintang sepanjang 22,5 km darisebelah barat berbatasan dengan Sungai Luk Ulo dan sebelah timur berbatasan dengan Sungai Wawar. Berdasarkan asal usul tanah wilayah Urutsewu terdapat dua versi yaitu berdasarkan pendapat negara dan masyarakat. Selain itu asal usul tanah Urutsewu juga tidak terlepas dari sejarah dan aturan hukum yang mengatur di Indonesia. Wilayah pesisir selatan Kabupaten Kebumen yang lebih dikenal sebagai wilayah Urutsewu memiliki potensi pariwisata dan budaya. Oleh karenanya penguasaan dan pengelolaan tanah harus secara bijak dan berwawasan lingkungan.

Berdasarkan bukti kepemilikan tanah wilayah Urutsewu milik Negara yang dikuasakan kepada TNI AD. Adapun klaim TNI AD memiliki sejumlah bukti bahwa wilayah Urutsewu dikuasakan kepada TNI AD yang dipergunakan bagi lokasi pertahanan nasional yang salah satu kegiatannya adalah sebagai lokasi latihan tembak. Bukti kepemilikan tanah Negara antara lain Surat Penerangan dari Pusat Kaveleri tentang Penggunaan Lapangan Tembak kepada Glondong Ambal Resmi Tanggal 28 Maret 1957; Surat Kepala Daerah TK II Kebumen Nomor 590/1404 Tanggal 31 Juli 1989 tentang Rekomendasi Pekerjaan Penambahan Fasilitas Bangunan Uji Coba Ambal Kebumen; Data Departemen Keuangan Republik Indonesia Dirjen Pajak Inspeksi luran Pembangunan Daerah Kantor Dinas Luar TK.I Purworejo; Surat dari Kementerian Keuangan RI Direktorat Jenderal Kekayaan Negara Nomor S-825/KN/2011; Perda Kabupaten Kebumen No. 23 Tahun 2012 tentang RTRW Kabupaten Kebumen tahun 2011-2013; Keputusan Kepala Kantor Pelayanan Perizinan Terpadu dan Penanaman Modal Kabupaten Kebumen Nomor 590/04/KEP/2013; Putusan Mahkamah Agung RI Nomor 05/P/HUM/2011; dan Surat Komisi Nasional Hak Asasi Manusia Indonesia Nomor 112/K/PMT/I/2011.

Selain bukti-bukti asal usul tanah milik negara di atas, masyarakat juga memiliki bukti kepemilikan tanah seperti di Desa Wiromartan terdapat denah tanah a.n. Djojo Sipon C. No: 57 dengan luas tanah $6.564 \mathrm{~m} 2$ dan dibatasi oleh pagar TNI yang terdapat pula luas tanah 1.586 m2 dan terdapat 49 Letter $C$ di Persil 59 dan 68 yang disengketakan dengan luas total tanah sengketa 182.835 m2; Desa Mirit Petikusan terdapat Persil 81, 82 dan 85 di tanah sengketa dengan luas tanah yang disengketakan (di dalam pagar) $7.100 \mathrm{m2}$; Desa Mirit luas lahan total 149.573 m2 dan luas yang kena pagar 14.957 m2; Desa Kaibon Petangkuran terdapat Sertifikat Hak Milik No. 145 Desa Petangkuran a.n. Tupan tahun 1964 (tercatat di buku tanah di BPN); Desa 
Entak terdapat Sertifikat Hak Milik No. 127 Desa Entak a.n. Musripah (terdaftar di buku tanah di BPN). Luas tanah sengketa Desa Entak (dalam pagar) 334.079 m2; Desa Brecong terdapat Sertifikat Hak Milik No. 155 Desa Brecong a.n. Rutiyah (tanah Negara bekas Objek LR). Luas total tanah sengketa Desa Brecong (dalam pagar) 1.001.678 m2; Desa Setrojenar terdapat Sertifikat Hak Milik No. 20, 21, 22 dan 23 Desa Setrojenar a.n. Sanmarjo tahun 1969 yang tercatat di buku tanah di BPN dan Sertifikat Hak Milik No. 28 Desa Setrojenar a.n. Mihad tahun 1969 yang tercatat di buku tanah di BPN; dan Desa Ayam Putih terdapat bukti C desa di Kawasan DV.

Dari sudut pandang masalah inti konflik yang terjadi di wilayah Urutsewu adalah perebutan lahan di sekitar Kebumen wilayah selatan yang terdiri dari Kecamatan Buluspesantren, Ambal dan Mirit. Konflik memuncak pada peristiwa 16 April 2011, terjadi perusakan oleh warga Setrojenar terhadap fasilitas-fasilitas TNI AD, kemudian TNI AD sudah bersiap siaga menghadang warga dan peristiwa tersebut membuat suasana desa menjadi mencekam dan penuh dengan ketakutan. Konflik tersebut kemudian meredam kembali, walaupun masyarakat sebagai korban penganiayaan terus melakukan advokasi dibantu dengan LSM (TAPUK dan FPPKS). Karena dilakukan pembiaran terhadap konflik setelah dua tahun pasca kejadian April 2011, konflik tersebut kembali muncul dengan isu-isu yang bertambah rumit dan aktor-aktor yang bertambah. Namun masalah intinya tetap sama yakni perebutan lahan sengketa antara masyarakat (petani Urutsewu) dengan TNI AD dan pemerintah.

Penyebab konflik yang terjadi, berdasarkan peta konflik di atas adalah karena penetapan lahan Hankam berjarak 1.000 meter dari bibir pantai, status tanah yang tidak jelas kepemilikannya baik dari masyarakat dan TNI AD, dan perusakan fasilitas TNI oleh masyarakat. Penyebab lainnya adalah adanya izin bagi penambangan pasir oleh PT. MNC dari Pemerintah Kabupaten Kebumen dan rencana pelebaran JJLS yang akan membutuhkan lahan yang menjadi sengketa menjadi penyebab hadirnya puncak konflik kedua. Efek dari adanya konflik tersebut adalah kerugian masyarakat yang merasa takut untuk beraktifitas. Kerugian terbesar oleh masyarakat adalah karena mereka hanya dibantu oleh LSM untuk melawan suatu lembaga keamanan negara dengan kekuatan bersenjata yang memiliki kekuatan dukungan besar baik Pemerintah Pusat maupun Pemerintah Kabupaten Kebumen. Efek sangat terasa ketika pasca peristiwa 16 April 2011, diantaranya adalah penembakan, ketakutan masyarakat, rasa dendam dan kerusakan.

Proses panjang keributan status tanah yang melibatkan masyarakat dengan TNI AD di wilayah Urutsewu sangat panjang dan belum menemukan titik temu untuk menyelesaikan kesalahpahaman tersebut. Upaya Pemerintah Kabupaten Kebumen sebagai perpanjangan tangan pemerintah pusat dalam menyelesaikan keributan tersebut hanya sudah dimulai sejak tahun 2007 hingga 2015 dengan berbagai strategi. Beberapa strategi itu diantaranya, Pertama, conciliation. Pada tanggal 8 November 2007 telah dilaksanakan musyawarah permasalahan tanah TNI di Pendopo Kecamatan Buluspesantren yang dihadiri oleh Muspika, Kodim 0709/Kebumen, Sidam IV Purworejo, Dislitbang Buluspesantren, Kepala Desa Ayamputih, Setrojenar dan Brecong, Ketua BPD 3 Desa, Mantan Kepala Desa Setrojenar (2 orang) dan warga masyarakat dari 3 Desa. Hasil musyawarah tersebut adalah masyarakat meminta untuk dilakukan pengukuran ulang atas batas tanah TNI $500 \mathrm{~m}$ dari 
bibir pantai, pemasangan patok pembatas harus dicabut dan diganti dengan tanda lain bukan tanda TNI AD serta kedua belah pihak tidak saling klaim atas status tanah.

Strategi kedua adalah arbitration. Tanggal 18 April 2008 di Gedung F Ruang Rapat Bupati Kebumen, telah diadakan Audensi antara FPPKS yang dipimpin oleh Sdr. Seniman berjumlah 50 orang dengan unsur Pemerintah Kabupaten Kebumen, Kantor Pertanahan Kebumen dan Kodim 0709/Kebumen yang merupakan tindak lanjut dari pertemuan di DPRD Kebumen pada tanggal 13 Desember 2007. Ketiga adalah compromise. Silaturahmi antara TNI AD, Pemerintah Kabupaten Kebumen dengan Tokoh Masyarakat Urutsewu pada hari Selasa tanggal 20 Oktober 2009 bertempat di Aula Rumah Dinas Bupati Kebumen, disepakati: permasalahan tanah Dislitbang TNI AD dengan masyarakat Urutsewu Kebumen untuk sementara menjadi Status Quo, artinya penggunaan lahan untuk kegiatan dilaksanakan seperti sebelum ada permasalahan (TNI dapat melaksanakan latihan seperti sediakala dan petani dapat melaksanakan kegiatan bercocok tanam).

Strategi keempat adalah stelemate. Peninjauan lapangan dilakukan tanggal 24 Maret 2011 oleh Bupati Kebumen didampingi Kapolres Kebumen, Ketua DPRD Kebumen, Asisten Pemerintahan, Kabag Tata Pemerintahan, dan Kantor Pertanahan Kebumen. Bupati menegaskan bahwa Pemerintah Kabupaten Kebumen tidak dapat memutuskan sendiri permasalahan tanah di wilayah Urutsewu karena Pemerintah Pusat dan Pemerintah Provinsi telah memutuskan wilayah tersebut diperuntukan untuk kepentingan pertahanan dan keamanan nasional. Terakhir, kelima adalah mediation. Pada tanggal 28 April 2011 FPPKS mengadakan audensi dengan Kakanwil BPN Provinsi Jawa Tengah di Semarang dengan kesimpulan: BPN tidak memiliki bukti kepemilikan atas hak dari masyarakat di lokasi konflik Desa Setrojenar, Kecamatan Buluspesantren; apabila masyarakat merasa memiliki bukti kepemilikan tanah supaya ditunjukan kepada Kantor Pertanahan Kebumen dengan membawa bukti asli yang dapat dipertanggungjawabkan; BPN tidak akan mempersulit pelayanan kepada masyarakat asal melalui prosedur dan tata cara aturan yang berlaku. Sementara itu pada tanggal 16 September 2015 melalui Pj. Bupati Kebumen membentuk tim mediasi guna menyelesaikan permasalahan tanah Urutsewu yang diketuai oleh Prof. Indra Bastian, Ph.D, MBA, CA, CMA (Pusat Mediasi Indonesia UGM), yang beranggotakan Dr. Ir. Cahyo Arianto, SH, M.Hum dan Sarjita, SH, M.Hum (STPN), Ir. Joko Budiyanto, SH, MM dan Muh. Nurdin, ST, MT (Kanwil BPN Provinsi Jawa Tengah) serta Yoyok Hadi Mulyo Anwar, SH dan Heri Susanto, A.Ptnh, MM (Kantor Pertanahan Kabupaten Kebumen).

\section{Analytical Hierarchy Process (AHP)}

Struktur hierarki keputusan dibuat dengan berdasarkan hasil kuesioner pertama yang dibagikan kepada sampel expert, yang kemudian hasilnya akan menjadi struktur hierarki dan kemudian dinilai tingkat konsistensinya untuk mengetahui strategi atau alternatif yang akan menjadi prioritas yang akan ditentukan dari hasil perhitungan kuesioner kedua. Kriteria, sub kriteria dan alternatif resolusi konflik pertanahan yang digunakan dalam hierarki diperoleh melalui tahapan studi literatur, kemudian kriteria, sub kriteria dan alternatif resolusi konflik pertanahan tersebut disusun agar lebih sistematis ke dalam hierarki. Indikator atau faktor-faktor yang digunakan dalam proses analisis hierarki terbagi menjadi 3 level, dari level yang paling rendah (kriteria) hingga ke level 
tertinggi (goal). Adapun tujuan (goal) yang ditetapkan adalah alternatif resolusi konflik pertanahan. Sedangkan kriteria dan sub kriteria ada tiga, yakni: a) Mencegah konflik terbuka: secara penelitian mendalam, pendekatan budaya lokal, bersikap masa bodoh (lumping it) dan avoidance; b) Mereda konflik: secara pemecahan masalah secara partisipatif, diskusi kelompok (FGD) dan Perencanaan Strategis; c) Menyelesaikan konflik: secara arbitrase, negosiasi, mediasi, advokasi, adjudikasi, kekerasan/koersi dan aksi legislatif.

Berdasarkan hasil analisis Kuesioner Tahap I tersebut diatas, skala penilaian yang dianggap logis pada skala 4, sehingga kriteria utama dan sub kriteria yang memiliki nilai rata-rata sama dengan atau lebih 4 yang akan disusun sebagai hierarki dan akan digunakan untuk mencari alternatif resolusi konflik pertanahan. Untuk kriteria utama mencegah konflik terbuka pada sub kriteria bersikap masa bodoh (lumping it) dan avoidance serta pada kriteria penyelesaian konflik, sub kriteria arbitrase dan koersi tidak dimasukkan hierarki karena nilai rata-rata yang didapat kurang dari 4. Struktur hierarki dibuat untuk mempermudah pengambil keputusan dalam melihat permasalahan dengan lebih terstruktur sehingga dapat diambil alternatif resolusi konflik pertanahan sehingga tujuan yang ingin diinginkan dapat tercapai.

Hasilnya ditemukan bahwa menurut tingkat kepentingannya, kriteria menyelesaikan konflik memiliki bobot yang paling tinggi yakni sebesar 0,575 , selanjutnya disusul oleh kriteria mencegah konflik terbuka sebesar 0,275, dan terakhir diisi oleh kriteria mereda konflik sebesar 0,150. $\mathrm{Hal}$ ini dinilai oleh para responden dengan anggapan bahwa, menyelesaikan konflik serta sub kriteria yang ada di dalamnya memiliki tujuan yang luas dan mendasar, serta dipandang lebih strategis dalam mencapai tujuan untuk mencari alternatif resolusi konflik pertanahan di wilayah Urutsewu Kebumen. Kemudian diikuti dengan cara mencegah konflik terbuka dengan anggapan para responden bahwa dengan cara mencegah konflik agar tidak meluas akan lebih mampu mencapai tujuan atau sasaran yang ingin dicapai dari sebuah alternatif resolusi konflik di wilayah Urutsewu Kebumen. Konsistensi rasio dari pembobotan kriteria utama sebesar 1,99 yang berarti secara umum jawaban responden konsisten dalam menentukan bobot kriteria utama dalam menentukan prioritas alternatif resolusi konflik pertanahan di wilayah Urutsewu Kebumen.

Pembobotan yang paling tinggi adalah menyelesaikan konflik yang menggambarkan bahwa keterlibatan semua pihak baik yang secara langsung terkena dampak konflik maupun yang tidak terlibat dan terkena dampak secara langsung. Selain itu cara mereda konflik juga masih diperlukan dalam strategi mengurangi konflik terbuka dan munculnya konflik baru. Diharapkan dengan adanya strategi menyelesaikan konflik dengan dukungan mencegah konflik agar tidak terbuka serta mereda konflik yang terjadi di wilayah Urutsewu Kebumen dapat diselesaikan dengan tidak meninggalkan kerugian dan kepentingan beberapa pihak.

Berdasarkan perhitungan bobot untuk menentukan skala prioritas pada kriteria yang berada pada level 2. Menurut tingkat kepentingannya perhitungan bobot pada kriteria dari mencegah konflik terbuka, penelitian mendalam menempati prioritas tertinggi dengan bobot 0,550, yang kemudian diikuti oleh sub kriteria dengar pendapat umum dengan jumlah bobot sebesar 0,240 dan terakhir adalah sub kriteria pendekatan budaya lokal/kearifan lokal sebesar 0,210. Bobot prioritas kriteria pada kriteria mencegah konflik terbuka menunjukkan sub kriteria penelitian 
mendalam tidak menurun dan memiliki bobot tertinggi. Hal tersebut menyatakan bahwa kedua sub kriteria lain yaitu dengar pendapat umum dan pendekatan budaya lokal/ kearifan lokal akan dapat dilakukan jika pendekatan penelitian secara mendalam dilakukan terlebih dahulu. Penelitian secara mendalam merupakan kajian secara akademis yang dilakukan oleh pihak akademisi (perguruan tinggi) yang dianggap sebagai pihak yang independen tanpa memihak dan memiliki kepentingan apapun. Perlu adanya mitra antar Pemerintah Kabupaten Kebumen dengan Perguruan Tinggi di Indonesia untuk mengkaji secara ilmiah dan akademis, sehingga pendapat dan masukan masyarakat dapat terakomodasi dalam kajian akademik. Tujuan penelitian mendalam tersebut akan digunakan oleh pemerintah daerah untuk menentukan kebijakan dalam menyusun alternatif resolusi konflik pertanahan di wilayah Urutsewu kebumen.

Berdasarkan pada bobot prioritas pada kriteria mereda konflik, perencanaan strategis dengan pembuatan kebijakan mendapatkan prioritas tertinggi dengan nilai 0,543, kemudian diikuti oleh memecahkan masalah secara partisipatif sebesar 0,382 dan terakhir ialah sub kriteria melakukan focus group discussion (FGD) dengan nilai 0,077. Berdasarkan gambaran tersebut terlihat bahwa perencanaan strategis dengan pembuatan kebijakan menjadi priortitas utama yang dipilih oleh para responden dengan nilai 0,543 menunjukkan bahwa merencanakan kebijakan strategis menjadi salah satu strategi penentu dalam keberhasilan resolusi konflik pertanahan wilayah Urutsewu yang masih berlangsung sampai saat ini karena masih terdapat kesalahpahaman atas status tanah yang disengketakan. Kemudian memecahkan masalah secara partisipatif, hal ini dikarenakan memecahkan masalah secara partisipatif dilaksanakan jika kebijakan strategis pemerintah telah di buat dan disosialisasikan. FGD diperlukan karena menurut responden kegiatan tersebut dapat memberikan sumbangan terhadap perumusan dalam menyelesaikan konflik pertanahan di wilayah Urutsewu.

Sementara untuk perhitungan bobot untuk kriteria menyelesaikan konflik, bobot prioritas yang tertinggi pada sub kriteria mediasi dengan nilai 0,411, kemudian diikuti sub kriteria negosiasi sebesar 0,251, lalu disusul oleh sub kriteria advokasi sebesar 0,148, sub kriteria adjudikasi sebesar 0,109 serta aksi legislatif yang memiliki bobot paling rendah yaitu senilai 0,082. Mediasi mendapat bobot paling tinggi, hal ini menunjukkan bahwa mediasi masih menjadi prioritas untuk ditingkatkan, karena sejalan dengan hasil survei ke masyarakat aspek mediasi masih menjadi jalan tengah guna menyelesaikan konflik pertanahan di wilayah Urutsewu. Artinya, aspek mediasi menjadi hal yang harus diprioritaskan terhadap menentukan resolusi konflik pertanahan yang akan ditentukan selanjutnya.

Selain itu aspek mediasi juga menjadi faktor yang menentukan dalam keberhasilan resolusi konflik pertanahan karena terkait erat dengan aspek kooperatif/ kerjasama dari masyarakat dan TNI AD sebagai pihak yang berkonflik. Kemudian strategi negosiasi merupakan bagian dari proses mediasi tersebut, sehingga kepentingan kedua belah pihak dapat terakomodir dalam hasil mediasi tersebut. Strategi advokasi dilakukan untuk mendapatkan keadilan dalam hukum yang berlaku di Indonesia. Sedangkan strategi adjudikasi dan aksi legislatif merupakan alternatif setelah mediasi, negosiasi dan advokasi hukum dilakukan. DPRD Kabupaten Kebumen merupakan perwakilan rakyat, sehingga diharapkan mampu menjadi perpanjangan tangah dan mencari jalan tengah atas 
konflik yang terjadi selama ini. Selain itu aksi legislatif diperlukan untuk meminta bantuan kepada anggota legislatif/ DPRD sebagai wakil rakyat di pemerintah, selain itu DPRD diyakini mampu memberikan akses kepada pihak berwenang khususnya Pemerintah Pusat untuk menyelesaikan konflik pertanahan wilayah Urutsewu.

Secara umum, menurut bobot tingkat kepentingan atau prioritas terhadap tujuan (goal) alternatif resolusi konflik pertanahan di wilayah Urutsewu (level O), sub kriteria mediasi memiliki bobot tertinggi dengan nilai 0,236 . Kemudian diikuti oleh sub kriteria penelitian mendalam dengan bobot sebesar 0,151 . Sub kriteria lain yang memiliki bobot cukup tinggi ialah sub kriteria negosiasi dengan nilai bobot sebesar 0,144. Penilaian terhadap tingkat kepentingan atau prioritas secara umum dari alternatif resolusi konflik pertanahan untuk mencari solusi konflik perebutan tanah di wilayah Urutsewu Kebumen antara lain strategi untuk mencegah konflik terbuka mendapatkan prioritas tertinggi dengan bobot 0,661. Kemudian diikuti oleh startegi untuk menyelesaikan konflik dengan nilai prioritas 0,214. Sedangkan strategi untuk mereda konflik mendapat bobot paling kecil dengan nilai 0,150 .

Strategi untuk mencegah konflik terbuka dipilih oleh responden dengan mendapatkan prioritas paling tinggi, jumlah yang signifikan tinggi dibandingkan dengan kedua strategi lain karena responden beranggapan bahwa konflik yang berlangsung sampai saat ini dan belum ada resolusinya, perlu adanya pencegahan agar konflik tersebut tidak meluas pada lini kehidupan masyarakat dan kepentingan lainnya. Selain itu upaya mencegah konflik terbuka dilakukan dalam menjalankan aktivitas masing-masing pihak terutama masyarakat Urutsewu dan TNI AD dapat berjalan secara aman dan damai tanpa ada keributan dan kesalahpahaman yang semakin meluas. Strategi resolusi konflik selanjutnya dengan prioritas kedua yaitu dengan menyelesaikan konflik. Perlu adanya suatu kondisi untuk menyelesaikan konflik, hal ini dapat ditempuh jalan dengan cara mediasi, sebagaimana disebutkan bobot tertinggi pada sub kriteria yang masuk dalam strategi menyelesaikan konflik sebesar 0,042.

Strategi untuk mencegah konflik terbuka terutama pada prioritas umum dari sub kriteria mediasi, sub kriteria penelitian mendalam dan sub kriteria negosiasi. Ketiga sub kriteria tersebut dipilih oleh responden dikarenakan mereka berpendapat bahwa ketiga sub kriteria tersebut berpotensi untuk mencegah konflik terbuka agar tidak meluas dengan konflik lainnya yang akan terjadi di wilayah Urutsewu, sehingga diperlukan strategi khusus yang mampu mengakomodasi ketiga kategori tersebut agar manfaat yang didapatkan terutama pada kedua belah pihak yang berkonflik yaitu masyarakat Urutsewu dan TNI AD benar-benar nyata.

\section{Analisis Stakeholders dan Politik Pertanahan di Urutsewu}

Salah satu konflik pertanahan yang terjadi antara masyarakat dengan TNI AD serta perusahaan (PT. MNC) yang hingga kini belum menemukan jalan penyelesaian yang pasti di Kabupaten Kebumen khususnya wilayah Urutsewu. Situasi konflik yang sudah terjadi dari dulu hingga sekarang telah banyak merugikan beberapa pihak termasuk masyarakat yang tidak memiliki kepentingan dalam sengketa tersebut. Konflik pertanahan Urutsewu merupakan sebuah potret kejadian dalam kurun 
waktu yang sangat panjang. Dalam kurun waktu yang sangat panjang telah melibatkan beberapa pihak dalam konflik tersebut.

Adapun stakeholders yang terlibat dalam konflik Urutsewu Kebumen setidaknya ada tujuh pihak. Pertama adalah TNI AD. Adapun TNI ADA bagian dari TNI yang berperan sebagai alat negara dalam pertahanan darat. Fungsi TNI AD adalah sebagai penangkal terhadap setiap bentuk ancaman militer dan ancaman bersenjata dari luar dan dalam negeri terhadap kedaulatan, keutuhan wilayah dan keselamatan bangsa; selain itu TNI AD juga berfungsi sebagai penindak terhadap setiap bentuk ancaman terkait dengan kesatuan bangsa serta pemulihan terhadap kondisi keamanan negara di darat yang terganggu akibat kekacauan keamanan.

Kedua adalah masyarakat (Kontra TNI AD). Urutsewu merupakan wilayah yang sangat subur untuk pertanian. Masyarakat menggantungkan hidup dari hasil pertanian dan mengembangkan usaha peternakan. Ketergantungan masyarakat pada tanah membuat mereka meyakini falsafah Jawa "sadhumuk bathuk sanyari bumi, yen perlu ditohi pati" yang berarti, walaupun hanya menyentuh kening atau sejengkal tanah, akan dibela sampai mati. Falsafah ini menunjukkan betapa eratnya hubungan antara manusia dan tanah. Pertanian di wilayah pesisir ini menghasilkan semangka, melon, sayuran, ubi, dan padi. Dari hasil itulah masyarakat memperoleh pendapatan dan bertahan hidup. Jumlah petani di Urutsewu terhitung besar.

Ketiga adalah Perusahaan Swasta. Investor yang akan melakukan penambangan pasir besi adalah PT Mitra Niagatama Cemerlang (PT MNC). Akta pendirian PT MNC disahkan oleh Departemen Kehakiman dan Hak Asasi Manusia bernomor 22 pada 24 Februari 1999. Perusahaan ini mengalami perubahan pada akta bernomor 4 tanggal 4 Februari 2010. Keberadaan PT MNC yang terhitung baru dalam penambangan pasir besi tidak bisa dipisahkan dari keberadaan PT NTC, PT Bara Adhipratama, maupun PT Bungo Raya Nusantara dari segi kepemilikan dan inti bisnisnya. Oleh karena PT MNC belum memiliki rekam jejak, ada baiknya untuk melihat sepak terjang perusahaanperusahaan yang terkait dengan PT MNC guna mendapatkan gambaran mengenai perusahaan ini.

Keempat adalah Pemerintah Kabupaten Kebumen. Penambangan pasir besi di Kebumen dilakukan sejak masa kepemimpinan Bupati Rustriningsih, periode 2005-2010. Namun, pada 2008 Rustriningsih mengundurkan diri karena terpilih menjadi Wakil Gubernur Jawa Tengah. Penggantinya adalah Mohammad Nashiruddin Al Mansyur yang menjabat untuk periode 20082010. Proses eksplorasi tambang pasir besi dimulai sejak 2008 ketika Nashiruddin menjadi Bupati Kebumen. la pula yang memberikan surat kepada Badan Lingkungan Hidup Jawa Tengah mengenai kesesuaian lokasi rencana penambangan pasir besi oleh PT MNC pada 16 April 2010. Hingga akhirnya jabatan Bupati dipegang oleh Buyar Winarso dan Djuwarni, dimana Buyar Winarso yang berlatar belakang dari pengusaha. Persoalan penambangan pasir besi di Kecamatan Mirit menjadi tanggung jawab dari Panitia Khusus (Pansus) I/DPRD yang diketuai oleh Muhayat (Partai Persatuan Pembangunan). Pansus I/DPRD yang dibentuk berdasarkan surat keputusan DPRD ini bertanggung jawab menyusun rancangan peraturan daerah (raperda) pertambangan mineral dan batubara. Oleh karena itu, persoalan mengenai penambangan pasir besi masuk dalam pembahasan pansus ini. 
Kelima adalah LSM. Penambangan pasir besi di Kecamatan Mirit memicu penolakan dari masyarakat. Penolakan ini disatukan dalam perkumpulan yang dipimpin oleh elite informal. Salah satunya adalah Forum Masyarakat Mirit Selatan (FMMS). FMMS merupakan forum warga dari enam desa di Kecamatan Mirit yang wilayahnya masuk area penambangan. Desa-desa tersebut meliputi Desa Mirit, Mirit Petikusan, Tlogodepok, Tlogopragoto, Lembupurwo, dan Wiromartan. Koordinator forum ini di tingkat kecamatan dipegang oleh Bagus Wirawan, warga Desa Lembupurwo yang memiliki usaha pertanian cabai dan kopra. FMMS menjadi forum yang berfungsi sebagai penyalur aspirasi dan penampung pendapat masyarakat desa. Hal ini karena kepala desa cenderung pasif dan kurang berinisiatif dalam menghadapi kegelisahan masyarakat terkait penambangan pasir besi.

Keenam adalah Masyarakat (Pro TNI AD). Keberadaan masyarakat yang berkonflik terbagi dalam dua kubu yaitu kubu kontra dengan TNI AD serta kubu pro TNI AD. Masyarakat Pro TNI $A D$ memiliki peran yang tidak terlihat dan tidak begitu memberikan kontribusi dengan adanya konflik tersebut. Masyarakat lebih cenderung diam dan acuh terhadap kondisi konflik yang terjadi di wilayahnya. Sebagian masyarakat mengaku tidak memiliki andil dalam konflik tersebut.

Sedangkan untuk analisis politik pertanahan bisa dibaca bahwa kasus konflik pertanahan wilayah Urutsewu terletak pada aspek kekuasaan pemerintah baik legislatif maupun eksekutif dalam mengelola sumber daya di Kabupaten Kebumen. Selain itu lembaga yudikatif yang berfungsi sebagai penengah dalam berbagai aspek konflik di Indonesia juga memiliki peran penting dalam menangani dan menengahi kasus Urutsewu. Pada dasarnya, Kepala Badan Pertanahan Nasional Republik Indonesia yang berwenang memberikan hak atas tanah negara kepada perseorangan atau badan hukum. Dalam pelaksanaannya dapat dilimpahkan kepada Kepala Kantor Wilayah Badan Pertanahan Nasional Propinsi atau Kepala Kantor Pertanahan Kabupaten/Kota. Peraturan yang mengatur kewenangan dalam pemberian hak atas tanah negara adalah Peraturan Menteri Negara Agraria/Kepala Badan Pertanahan Nasional Nomor 3 Tahun 1999 tentang Pelimpahan Kewenangan Pemberian dan Pembatalan Keputusan Pemberian Hak Atas Tanah Negara. Peraturan Menteri Negara Agraria/Kepala Badan Pertanahan Nasional Nomor 3 Tahun 1999 menyatakan tidak berlaku Peraturan Menteri Dalam Negeri Nomor 6 Tahun 1972 tentang Pelimpahan Kewenangan Pemberian Hak Atas Tanah. Tata cara pemberian hak atas tanah negara diatur dalam peraturan Menteri Negara Agraria/Kepala Badan Pertanahan Nasional Nomor 9 Tahun 1999 tentang Tata cara Pemberian dan pembatalan Hak Atas Tanah Negara dan Hak Pengelolaan.

DPRD Kabupaten Kebumen sebagai lembaga legislatif daerah yang dipilih melalui pemilihan umum yang langsung dipilih oleh rakyat, memiliki tanggungjawab terhadap daerah konstituennya. Oleh karena itu DPRD bersama Pemerintah Kabupaten Kebumen (eksekutif) bersama-sama memberikan pelayanan dan perlindungan terhadap masyarakat wilayah Urutsewu dengan adanya Perda No. 23 Tahun 2012 tentang RTRW Kabupaten Kebumen. Akan tetapi perda tersebut menimbulkan kerisauan masyarakat terhadap keberlangsungan sumber daya alam di wilayah pesisir Kebumen.

Kerisauan tersebut dikarenakan pemerintah daerah memberikan ijin terhadap perusahaan swasta untuk mengeksploitasi tambang pasir besi di wilayah Kecamatan Mirit. Masyarakat sangat menyayangkan kejadian tersebut, dikarenakan wilayah penambangan pasir tersebut akan 
berdampak pada keberlangsungan kesuburan tanah dan kerusakan lingkungan lainnya. Selain peran pemerintah, aparat penegak hukum yaitu Kepolisian Republik Indonesia (Polri) memiliki peran dalam penanganan penyelesaian sengketa pertanahan di Indonesia. Dalam penyelesaian sengketa pertanahan di Indonesia Badan Pertanahan Nasional Republik Indonesia dan POLRI membuat surat keputusan bersama yang dituangkan dalam Memorandum of Understanding (MoU) BPN RI dengan POLRI melaui SKB Nomor 10/SKB/XII/2010 - B/31/XII/2010 tanggal 3 Desember 2010 hal ini guna mempercepat penyelesaian masalah pertanahan yang ada. Adapun jalur khusus ini memuat tentang Sidik Sengketa yakni ada indikasi pidana, pelanggaran Undang-Undang. Yang kedua kerjasama dalam Tuntas sengketa yakni penyelesaian sengketa yang mendapat prioritas berpotensi untuk di mediasi.

\section{Alternatif Resolusi Konflik Pertanahan di Urutsewu}

Strategi mencegah konflik terbuka yang merupakan alternatif resolusi konflik efektif adalah dengan cara mediasi. Mediasi masih menjadi sarana yang efektif dalam pengambilan keputusan dalam mencegah konflik pertanahan di wilayah Urutsewu agar tidak meluas kepada permasalahan dan kepentingan lainnya. Beberapa masyarakat percaya dengan cara melibatkan pihak ketiga untuk membantu dalam pengambilan keputusan antar pihak yang berkonflik. Menurut Wehrmann (2008: 82) mediasi harus mensyaratkan agar pihak-pihak yang berkonflik saling bertemu dan menemukan kesepakatan. Mediator mengikuti prosedur yang ketat, memberi kesempatan kepada setiap pihak untuk menjelaskan persepsi dan mengutarakan pendapatnya. Menurut Moeliono (2003: 37) secara umum ada tiga golongan besar pengalaman mengelola konflik di Indonesia, yaitu: pengalaman dalam mencegah konflik semakin membesar, pengalaman dalam mengatasi konflik yang telah terjadi dan pengalaman mengelola konflik secara partisipatif.

Thompson dkk. (2005) menjelaskan bahwa metode partisipatif yang digunakan dalam menyelesaikan konflik sumber daya alam secara efektif mencakup dukungan penyusunan strategi secara partisipatif yang dilakukan oleh pihak yang berkonflik dengan adanya pemerintah baik eksekutif maupun legislatif serta pihak-pihak masyarakat yang sebelumnya tidak terlibat dalam pengambilan keputusan. Sedangkan Brody, Godschalk, \& Burby (2003) dalam penelitiannya terkait dengan partisipasi masyarakat dalam pemngambilan keputusan menjelaskan bahwa partisipasi masyarakat dalam perencanaan memiliki sejarah panjang dan penting, seperti pada Negara Bagian Amerika Serikat pada tahun 1920 pemerintah daerah mewajibkan memberi kesempatan kepada warganya untuk berpartisipasi dalam perencanaan pembuatan kebijakan. Adapun dalamn konteks upaya menyelesaikan konflik pertanahan wilayah Urutsewu Kebumen selama ini dilakukan oleh Pemerintah Kabupaten Kebumen belum sepenuhnya melakukan strategi partisipatif yang melibatkan masyarakat untuk pengambilan kebijakan. Contohnya adalah upaya mediasi pada tahun 2015 yang dilakukan oleh Tim Independen yang dibentuk oleh Pj. Bupati Kebumen dengan beranggotakan akademisi dan pemerintah (provinsi dan kabupaten) dengan strategi pengumpulan data bukti kepemilikan tanah.

Jika meninjau berdasarkan konflik pertanahan yang melibatkan TNI AD dengan masyarakat Urutsewu Kebumen, perlu adanya alternatif model resolusi konflik pertanahan yang bersifat 
demokratik. Permasalahan perebutan tanah yang melibatkan TNI AD dan masyarakat merupakan suatu permasalahan kompleks di tengah kehidupan bermasyarakat. Berdasarkan hasil penelitian, alternatif resolusi konflik pertanahan Urutsewu lebih menekankan untuk mencegah agar konflik tidak terbuka dan meluas pada bidang lainnya. Adanya upaya menyelesaikan konflik juga diperlukan agar terjadi harmonisasi dalam kehidupan bermasyarakat sehingga dibutuhkan usaha untuk meredakan konflik agar tidak berkepanjangan.

Upaya mencegah konflik terbuka dapat dilakukan dengan jalan mediasi, yakni penelitian mendalam oleh pihak independen (perguruan tinggi) dan upaya negosiasi antar pihak yang berkonflik. Ketiga upaya tersebut dipengaruhi oleh faktor kerusakan fasilitas umum yang diakibatkan puncak konflik (keributan) yang terjadi. Selain itu adanya ketidakjelasan hukum yang mengikat dari Negara atas hak milik tanah yang disengketakan. Negara memiliki peran penting dalam upaya mencegah konflik di wilayah Urutsewu Kebumen agar tidak melahirkan konflik-konflik baru disekitar pesisir Kebumen dan wilayah lainnya yang menjadi lokasi adanya TNI AD di tengah masyarakat. Beberapa faktor dan upaya tersebut dapat dilakukan secara partisipatif yang bertujuan untuk mencegah agar konflik tidak terbuka melalui mekanisme demokrasi.

Penyelesaian konflik juga harus mengedepankan mekanisme kearifan lokal. Upaya menyelesaikan konflik wilayah Urutsewu Kebumen juga dapat dilakukan dengan jalan mediasi dan negosiasi. Negara melalui pemerintah daerah baik Pemerintah Kabupaten Kebumen maupun Pemerintah Provinsi Jawa Tengah telah melakukan beberapa upaya mediasi dan negosiasi. Perlunya mekanisme kearifan lokal diperlukan dalam hal menelusuri asal usul tanah sebelum menjadi sengketa. Oleh karena itu diperlukan peran tokoh adat setempat yang didasari oleh kepercayaan (trust) masyarakat dan pemerintah. Modal sosial (social capital) juga diperlukan dalam upaya menyelesaikan konflik tersebut, melalui modal sosial yang dimiliki oleh masyarakat setempat dapat menjadi jalan dalam melakukan mediasi tanpa ada tekanan dari pihak ketiga. Sebagai pihak yang berkonflik adanya modal sosial memberikan ruang bebas dan terbuka dalam berpendapat sehingga semua aspirasi dan pendapat dapat tertampung dengan bijaksana.

Selain upaya mencegah dan menyelesaikan konflik, upaya mereda konflik juga diperlukan dalam alternatif resolusi konflik Urutsewu Kebumen. Alternatif dalam upaya mereda konflik dapat dilakukan dengan melibatkan akademisi. Pihak akademisi merupakan pihak independen yang tidak memiliki kepentingan apapun dalam konflik tersebut. Akademisi bekerja secara ilmiah dan tanpa adanya paksaan dari pihak yang berkonflik maupun pemerintah. Konsep pemetaan konflik yang memiliki nilai ekologi dan pemanfaatan tanah secara ekonomi dapat dilakukan secara non litigasi dengan peyelesaian konflik secara internal melalui peran aktor yang berkonflik serta komunikasi dengan bantuan pihak akademisi.

Artinya, kepemilikan tanah yang dikuasai oleh negara (state property) harus dikembalikan kepada kepemilikan secara komunal (common property). Di bawah kepemilikan oleh negara, pemerintah menjadi penguasa hak tunggal dari sumber daya, termasuk akses terhadap sumber daya itu dan menentukan tingkat penggunaannnya. Instrumen yang ada untuk mempengaruhi perilaku individu berkaitan dengan pengelolaan state property adalah zoning, pajak, peraturanperaturan dan perijinan. Sedangkan common property mencakup elemen-elemen: (a) sebuah 
kelompok yang terdefinisikan dengan jelas sebagai pemilik bersama, yang (b) mengembangkan atau menganut rejim pengelolaan yang terdefinisikan dengan jelas, dimana (c) pemilik bisa melakukan pelarangan akses dan mengeluarkan/melakukan pelarangan terhadap yang bukan pemilik dan meliputi (d) hak-hak dan tugas-tugas dari pemilik berkaitan dengan penentuan tingkat penggunaan dari sumber daya comon property tersebut (North, 1990: 103).

\section{Penutup}

Dari hasil analisis terhadap penentuan alternatif resolusi konflik pertanahan di wilayah Urutsewu Kebumen dari para expert yang merupakan stakeholders (terdiri dari aparat pemerintah desa baik yang pro dan kontra, TNI AD, lembaga eksekutif, lembaga legislatif dan LSM) yang pernah terlibat langsung dalam konflik maupun upaya menyelesaikan konflik yang pernah dilakukan, diketahui bahwa stakeholders lebih menginginkan konflik pertanahan di wilayah Urutsewu dilakukan pencegahan agar tidak meluas kepada konflik dan kepentingan lainnya. Hal ini dibuktikan dengan bobot prioritas tertinggi pada alternatif strategi resolusi konflik pertanahan. Ini artinya, dengan mencegah konflik secara terbuka, masyarakat, TNI AD dan pemerintah dapat bersinergi dalam rangka pembangunan nasional.

Prioritas strategi untuk mencegah konflik terbuka adalah dengan cara mediasi yang didorong oleh keinginan stakeholders untuk memecahkan masalah dengan cara penelitian mendalam dan dengan dukungan negosiasi antar pihak yang berkonflik. Strategi untuk mencegah konflik terbuka di Urutsewu terutama di dorong dengan cara mediasi yang mendapatkan bobot umum paling tinggi, kemudian dengan cara penelitian mendalam serta negosiasi. Alternatif resolusi konflik pertanahan di wilayah Urutsewu Kebumen dengan bobot tertinggi kedua yaitu menyelesaikan konflik dan terakhir dengan bobot paling rendah adalah mereda konflik. Adanya mediasi dalam menyelesaikan konflik pertanahan di wilayah Urutsewu harus dilakukan oleh Pemerintah Pusat mengingat status tanah merupakan Tanah Negara.

Konflik pertanahan di wilayah Urutsewu Kebumen pada dasarnya merupakan jenis konflik vertikal yang melibatkan TNI AD dengan masyarakat. Upaya yang telah dilakukan Pemerintah Kabupaten Kebumen selama ini belum memberikan resolusi dan jalan tengah antar kedua belah pihak yang berkonflik. Alternatif model resolusi konflik pertanahan di wilayah Urutsewu dengan mengedepankan model demokratik dengan cara mediasi yang dilakukan secara partisipatif. Model demokratik dijalankan dengan pemetaan ulang yang dilakukan oleh negara sebagai pemilik tanah serta mengubah state property ke common property. Artinya penguasaan sumber daya alam dikuasai oleh negara dan diperuntukan bagi kesejahteraan rakyat seperti yang tertuan dalam UUD 1945.

Meskipun demikian, penelitian ini masih memiliki kelemahan bahwa hasil penelitian ini hanya membahas tentang alternatif resolusi konflik pertanahan di wilayah Urutsewu Kebumen agar mampu mencegah konflik tidak terbuka. Akan tetapi disisi lain terdapat temuan bahwa pendekatan budaya lokal perlu dilakukan untuk menyelesaikan konflik tersebut. Jadi, penelitian ini memiliki missing link tentang strategi menyelesaikan konflik dengan pendekatan budaya lokal/kearifan lokal. 
Agar tidak terjadi konflik berkepanjangan, maka masyarakat dan TNI AD harus memverifikasi data faktual yang dapat dipertanggungjawabkan kepada instansi terkait. Masyarakat harus membuktikan bahwa kepemilikan tanah dengan cara menyerahkan dan memverifikasi dokumen kepada BPN Kabupaten Kebumen. Begitu juga dengan TNI AD harus menyelesaikan permasalahan keperdataan masyarakat dalam rangka tata tertib kelola aset TNI AD dengan cara musyawarah mufakat. Kemudian Pemerintah Kabupaten Kebumen sebagai perpanjangan tangan Pemerintah Pusat bersama dengan Lembaga Legislatif Daerah/DPRD harus memfasilitasi upaya Pemerintah Pusat dalam melakukan penyelesaian konflik pertanahan di wilayah Urutsewu Kebumen. Mengingat status tanah yang dipersengketakan adalah Tanah Negara, maka Pemerintah Pusat harus segera bertindak atas beberapa rekomendasi upaya penyelesaian yang pernah dilakukan sebelumnya, sehingga konflik tidak hanya di reda saja, akan tetapi dapat diselesaikan.

\section{Ucapan Terima Kasih}

Terima kasih pada responden dan informan yang telah terlibat dalam penelitian yang penulis lakukan.

\section{Pendanaan}

Penulis tidak menerima bantuan pembiayaan untuk penelitian, kepenulisan (authorship), dan publikasi dari pihak manapun.

\section{Daftar Pustaka}

Brody, S. D., Godschalk, D. R., \& Burby, R. J. (2003). Mandating Citizen Participation in Plan Making: Six Strategic Planning Choices. Journal of the American Planning Association, 69(3), 245-264. https://doi.org/10.1080/01944360308978018

Fisher, S., Abdi, D. I., Smith, R., Ludin, J., Williams, S., \& Williams, S. (2001). Mengelola Konflik: Keterampilan dan Strategi untuk Bertindak. Jakarta: The British Council.

Harsono, B. (2005). Hukum Agraria Indonesia, Sejarah Pembentukan Undang-Undang Pokok Agraria, Isi dan Pelaksanaanya. Jakarta: Djambatan.

Limbong, B. (2012). Konflik Pertanahan. Jakarta: Pustaka Margareta.

Moeliono. (2003). Memadukan Kepentingan Memenangkan Kehidupan: Buku Acuan Metodologi Pengelolaan Sengketa Sumber Daya Alam. Bandung: Studio Driyamedia.

Nader, L., \& Todd, H. F. (Eds.). (1978). The Disputing Process Law in Ten Societies. New York: Columbia Univesity Press.

North, D. C. (1990). Institutions, Institutional Change, and Economic Performance. Cambridge: Cambridge University Press.

Saaty, J. T. (2008). Decision Making with the Analytic Hierarchy Process. International Journal Services Sciences, 1(1). Diakses dari http://www.rafikulislam.com/uploads/resourses/19724 5512559a37aadea6d.pdf 
Susanto |Konflik dan resolusi konflik: Pendekaran analytical hierarchy process dalam konflik pertanahan...

Sumardjono, M. S. W. (1982). Puspita Serangkum Masalah Hukum Agraria. Yogyakarta: Liberty.

Thompson, J. R., Elmendorf, W. F., McDonough, M. H., \& Burban, L. L. (2005). Participation and Conflict: Lessons Learned From Community Forestry. Journal of Forestry, 103(4), 174-178. Diakses dari https://lib.dr.iastate.edu/cgi/viewcontent.cgi?article=1004\&context=nrem_pubs Wehrmann, B. (2008). Land Conflicts: A practical guide to dealing with land disputes. Deutsche Gesellschaft für Technische Zusammenarbeit.

\section{Tentang Penulis}

Susanto adalah Alumni Magister Ilmu Politik, Departemen Politik dan Pemerintahan, Fakultas IImu Sosial dan IImu Politik, Universitas Diponegoro. 